\title{
Quest for Love through Self-Exploration: Edna Wu's Women Narrators' Search for Fulfillment of the Body and Soul in the New Land
}

\author{
Heping Zhao \\ Department of English, California State University, Fullerton, USA \\ hzhao@fullerton.edu
}

\section{Doi:10.5901/ajis.2013.v2n8p752}

\section{Abstract}

Love, gender, sex, and sexuality are omnipresent and constantly intertwined with political and racial issues and other aspects of humanity in each one of Edna Wu's three books: Clouds and Rain: A China-to-America Memoir (1994), Two Eves in the Garden of Eden and a Male Mother (A Screen and a Play) (2006), and A Single-Winged Bird (2010). A Chinese immigrant, Edna Wu painstakingly examines what Jonathan Spence calls the "erotic and intellectual fulfillment" for her narrators in this new land of freedom. She, more than any other writers, male or female, who have left China and set up homes in America, uses a combination of genres and forms-from fiction to poetry and from memoir to drama-in exploring the Chinese immigrant's experience that embodies acute conflicts between the old and the new, the restricted and the free, and the East and the West. She is equally free in utilizing bilingualism in her writing to reveal the emotions of her characters and to enhance the crippling effects of the very act of uprooting oneself from one place in order to settle in another. These techniques that she so adeptly employs allow her to absorb deeply in her soul search in each of the three works. In this paper I attempt to analyze the theme of universal erotic love Edna depicts in the fictionalized experience of her narrators in the three works. Specifically, I elect to focus on the feministic perspective unique to Edna in seeking self-realization through unbounded means and approaches. In so doing I want to argue that, insofar as the purpose of migration is to start anew, women immigrants as portrayed by Edna seek their newness and renewed selfhood through a range of experiments unknown to them in the world they have come from. The free exploration of their own bodies and sexuality constitutes a major and primal part of these experiments.

Commenting on Bai Hua's 《苦恋》 [Unrequited Love] and other novels, Qingyun Wu notes, "Taken together, the[se] dramatic tragedies of sexual repression and monogamy comprise Bai Hua's indictment of patriarchy as a cause of all social evils" in the Maoist China, especially during the eleven-year period of the Great Cultural Revolution (Wu, Q. 1995. p. 125). Perhaps influenced by him as she worked on many of Bai Hua's works both as a translator and an analyst, Wu, "Qingyun" as her given name in Chinese, but "Edna" as her English penname, apparently shares the same view with him on the issue of sex. "Sex is a natural part of human life," Wu observes, "but men create laws and entire ideologies that make sex a matter of politics and property" (p. 125). Such laws and ideologies, in Wu's opinion, are to blame for all sorts of what she calls "patriarchal evils: sexual repression, sexual starvation, rape, prostitution, monogamy, adultery, jealousy, and murder" (p. 124). Exposing such evils and calling for sexual freedom are thus a pivotal component of her themes in the three literary works she has thus far published: Clouds and Rain: A China-to-America Memoir (1994), Two Eves in the Garden of Eden and a Male Mother (A Screen and a Play) (2006), and A Single-Winged Bird: Poems, A Short Novel, and One-Way Emails (2010).

The way Edna Wu tries to achieve her goal is by writing what appears to be autobiographical, using a genre that she calls "personal book." In her own definition, a "personal book" is "a sum total of genres as poetry, diary, letter/email, travelogue, prose and mini-fiction, and mini-drama or an amorphous mass of traditional, modern, postmodern or whatever nameless hodgepodge" (2010. p. xiii). In a manner similar to the Bakhtinian notion of "hybridization" (1981. P. 356) or deliberate mixing of an array of languages and forms, Edna Wu painstakingly explores for what Jonathan Spence sees as the "erotic and intellectual fulfillment" for her narrators both in the old country of China and in the new land of America. She, more than any other writers, male or female, who have left China and set up homes elsewhere, uses a combination of genres and forms-from fiction to poetry and from memoir to drama-in examining the Chinese immigrant's experience that embodies acute conflicts between the old and the new, the restricted and the free, and the East and the West. She is equally free in utilizing bilingualism in her writing to reveal the emotions of her characters and to enhance the crippling effects of the very act of uprooting oneself from one place in order to settle in another. These techniques that she so adeptly employs allow her to absorb deeply in her soul search in each of the three works.

All writing is necessarily autobiographical insofar as human beings are cognitively caged in their own egocentrism 
and ethnocentrism. In Edna Wu's arguably autographic writing, a notion she ostensibly disagrees with and, tongue in cheek, insists that her personal books are "fiction in the camouflage of a reality show" (2010. P. xiii), the "self" she writes about is a rather complex entity made up of personal experience, observations, and imaginations. The female narrator in each is simultaneously the product and process of many things. This multi-faceted persona, however, can be split into two halves in general. One half follows the social norm set up by socio-political conventions. The other half rebels again these very same conventions in an effort to seek emancipation and selfhood. In this sense, Edna Wu is, consciously or unconsciously, doing exactly what many women writers are doing as described by Sandra Gilbert and Susan Gubar in their Infection in the Sentence: The woman Writer and the Anxiety of Authorship:

\begin{abstract}
To heal herself, however, the woman writer must exorcise the sentences which bred her infection in the first place; ...... Or, to put the matter in terms of a different metaphor, to "set the crystal surface free," a literary woman must shatter the mirror that has so long reflected what every woman was supposed to be. For these reasons, then, women writers in England and America, throughout the nineteenth century and on into the twentieth, have been especially concerned with assaulting and revising, deconstructing and reconstructing those images of women inherited from male literature, especially as we noted in our discussion of the Queen's looking glass, the paradigmatic polarities of angel and monster. Examining and attacking such images, however, literary women have inevitably had consciously or unconsciously to respect the values and assumptions of the society that created these fearsome paradigms. Thus, even when they do not overtly criticize patriarchal institutions or conventions, these writers almost obsessively create characters who enact their own, covert authorial anger.... It is significant, then, that when the speaker of "the Other Side of a Mirror" looks into her glass the woman that she sees is a madwoman, "wild/With more than womanly despair," the monster she fears she really is rather than the angel she has pretended to be (Richter. 1998. p. 1365).
\end{abstract}

Of course, the "madwoman" Gilbert and Gubar describe in the above quote is in fact perfectly sane and normal. She is mad only in the eyes of the patriarchal world where rules of conduct have been set up to govern the way she behaves. Any deviation from such rules on her part would result in necessary madness. In this sense, Yun in Clouds and Rain is mad; the lesbian lovers in the Two Eves in the Garden of Eden are mad; Jenny Morita and Meiyin Hu in A Male Mother are mad; and the poetess, the diarist, and the one-way email writer in A Single-Winged Bird are all mad. In the pages below, I will take a close look at the madness of these women as depicted by Edna Wu. I will specifically focus on Wu's presentation of the sexuality of her female immigrating narrators/characters whose life's paths happen to "coincide" with that of the author. In so choosing, I will leave out one of her work, Two Eves in the Garden of Eden, out of this discussion because it is the only one whose theme does not involve immigration.

Edna Wu's depiction of sex is direct, graphic, detailed, and unapologetic. Although the acts of sexuality in her works range from incest to queer romance, heterosexuality is what she writes about the most. "After a few weeks of tears and pain," Edna Wu thus begins her 1994 novel, Clouds and Rain: A China-to-America Memoir, "I finally killed the angel of love in me..." (p. 6). She wastes no time to cast aside the socially conforming half, the one that stands outside of the mirror in Gilbert and Gubar's description. Now that the angel in Yun, the protagonist, is dead, she is ready to the let the mad demon take over. She immediately rushes to have Yun share with the reader the scene of her masturbation over the fantasy of Ramon: "she felt a tightening of her bras and a thrill shot up from the deep red valley, radiating through and through; nothing could help relieve such an intensity, except an auto-erotic release" (p. 6). Interestingly, Yun's longing for Ramon, a Mexican-American colleague, is greatly intensified mostly because he does not seek any sexual favor from Yun for helping her with her academic writing. An assistant professor at a state university in Los Angeles, Yun is faced with the same cruel "publish-or-perish" reality as anyone in the profession; however, being a new immigrant with English as her second language, she faces enormous challenges in writing and getting published. Her experience in seeking help in such matters has been one of "trade:" You pay for what you get, although the way of payment may vary. Everyone who has helped edit her writing in the past either demanded sex or money, often times both. She is used to such demands and willing to cut deals as in any business transaction. After all, this is America. There is no such a thing as a free lunch in this new country of her choosing. She must pay for what she wants. Sex is perhaps the easiest way to settle the transaction once the moral values are taken out of the equation. Ramon's not wanting such payback, paradoxically, greatly arouses her and sexually excites her. Frustrated at her failure in getting romantically involved with Ramon yet afraid of being so involved, Yun writes in Chinese verse, "Without clouds and rain/the friendship won't last long; With clouds and rain/the friendship won't last long" (p. 19).

This is a typical "Catch-22" situation. Without getting sexually involved, a woman cannot achieve a full friendship with a man; getting involved, her friendship with him cannot last long, either. Edna Wu here uses the Chinese metaphors of "clouds" and "rain" in reference to the act of sexual intercourse. She deliberately highlights Yun's bafflement and frustration as to whether she should aggressively pursue Ramon in order to enlarge the confusion and puzzlement that 
every immigrant, especially a female immigrant, constantly encounters in getting assimilated into this new culture and new country. While sexual freedom is held in high regard in this land of the free, uninvited sexual advances can have grave consequences as a form of sexual harassment. Yet, advance she must. This is not only necessary for her own body and mind, but also essential for her professional growth and personal relationship, knowing full well of the chances she must take in order to move ahead in this new environment.

If immigrants come to America to seek freedom and opportunities for self-betterment, sexual freedom and sexual fulfillment, as Edna Wu depicts them, would be the strongest representation of such freedom and a reliable symbol of their pursuit's success. The symbolic elements of sex and sexuality thus become omnipresent. To Yun, the cheese that stretches from the mouth to the hand as one takes a bite of the pizza exemplifies a woman's vaginal energy, while "the hotdog symbolizes phallic power" (p. 49). Similarly, "the shower head" is "shaped like a huge penis" and the hole in the bathtub, unsurprisingly, is seen as a woman's vagina (p. 62). To Yun, the power and strength of America do not lie in its military and economic might; rather they lie in its sexual drive and sexual energy. In contract, men in China, the country where she comes from, appear lethargic and impotent. Consequently, Yun sees China as a female body at best, her limbs tied to the four corners of the earth, being pumped almost too vigorously by an extra-large Western penis. She groans with pain and with pleasure, simulating an orgasm.

Edna Wu's examination of the role of sex continues to be a major part of her theme as she moves forward with her creative writing. Her second book, Two Eves in the Garden of Eden and a Male Mother (2006), bears much evidence of that continuation in the two parts of the book, the first part being a screenplay and the second, a play. As explained earlier, Wu's screenplay in this book is about two lesbian lovers-a daughter and a daughter-in-law-who are caught in the act of love-making by their father/father-in-law. Out of fear, and in what they feel as an act of self-defense, they kill the old man. Although the screenplay is every bit an exploration of sex and sexual freedom, I choose not to go into any analysis of it because it is set in China, without any resemblance of her other stories that all deal with the immigration of the female protagonist.

The second tale in the book, "A Male Mother," is about immigration of a different kind, and therefore very much in sync with Edna Wu's overarching theme about sex and sexuality in the new land. The play begins with Allen Morita and his wife Jenny Morita adopting an infant girl from a Chinese orphanage and ends with the trial for the rape and murder of that Chinese girl 16 years later. Its melodramatic conclusion has the girl suddenly run into the courtroom very much alive, thus showing an apparent contrast between the tragedy of real murder in the screenplay of "Two Eves" in China and the happiness of a grand reunion when the supposedly raped and murdered 16-year-old girl returns safe and sound in "A Male Mother" in America. This contrast, as Edna Wu wants us to believe, is the result of two strikingly different sociopolitical systems: one suppresses sex and sexual expressions of any kind, and the other guarantees freedom of love, sex, and sexual orientation of their own choosing. The author's intention is made clear through the words of Meiyin, Allen Morita's longtime lover, as she tries to confess to the killing of Alice, the girl whom Allen Morita adopted 16 years ago and has been mothering ever since:

I am a writer and can be carried away by my imagination. But the imagination is not always beautiful and noble. I have known Allen intimately for twelve years. Allen loves me mainly because of my free spirit... I was brought up in a totalitarian society [in China] where people were brainwashed to negate the self and individualism. Since coming to America in 1980, I have tried to act according to American values. What is feminist assertiveness? What is the concept of being self-centered? What is individualism? In the final analysis, all are beautified means of hiding selfishness for selfadvancement. In moments of confusion, my dark imagination overtook me. I imagined I knelt in a gold-gilded temple before the Bodhisattva and wished for the disappearance of Alice and Jenny as they are obstacles to my pursuit of love and happiness.

I admit that my imagination deserves legal punishment because it abuses and kills Alice-the living body of youth, innocence, and beauty (pp. 93-95).

The reader of the play knows that this is a false confession. It nonetheless summarizes the typical mindset of an immigrant woman who confuses sex and sexual desire with the pursuit of love and happiness in her adopted land. What constitutes happiness to Meiyin, the Chinese female immigrant author, is the freedom to "smoke, drink, and date men" ( $p$. 77). Acting upon her narrow, if not misguided, understanding of the American type of happiness, she, as an angel, pretends to live a single life without men since that appearance makes her look traditional, look Chinese, while in her secret reality, she is sexually involved with Allen, a married man with an adopted daughter. When conditions permit, Meiyin openly declares that she is "not an angel" (p. 78) as she appears to be. On the other side of the mirror, she sees herself every bit as mad as any other woman. Her obsession in love-making with Allen drives her wild with imaginations, 
including imaginations to kill his wife and daughter. That is why her confession of hiring a beggar to murder Alice seems credible in the courtroom.

Although less graphic, Edna Wu's depiction of love and sex remains thematic in her third and last book: A SingleWinged Bird (2010). The title of this book is a rather vague metaphor. Edna Wu wants to use it to convey her lack of love and everything else that love entails, including sex and other acts of intimacy. She makes a contrast between a "double-winged bird" and a "single-winged bird" in a one-way email to her imagined lover later in the book:

\begin{abstract}
“双翼鸟" (her original Chinese without English translation) [or a "double-winged bird" (the translation is my addition)] is perhaps the idealist image of love between a man and a woman. Yet in my life I have always been flying with one wing and this wing is very often in a broken condition. Perhaps, as you see, the only worth of me is perseverance-l will keep flying to my last breath in this world (p. 172).
\end{abstract}

The author's intentional mixing of languages and genres is at her freest and most deliberate in this book. Comprised of three parts, the book begins with a collection of poems that appear unrelated to each other. Each one is in both English and Chinese, without any indication as to which was the original and which the translation. The second part is what Edna Wu names "a short novel." By length, it is more like a short story rather than a novel, again both in Chinese and English. It is written in the form of a diary, each entry dated the $6^{\text {th }}$ of some months from September $6^{\text {th }}, 2001$ to June $6^{\text {th }}, 2052$. The diary documents a fifty-one-year imagined love affair between Edna-another coincident-and DC, both of whom grow to be over a hundred years old in the end. The third part, titled "One-Way Emails" with a very liberal Chinese translation 只见鱼往而不见雁来 (literally "only seeing the fish swimming away without any sight of the geese returning), echoes many of the scenes in the "Riddle" story, with some slight changes of the characters' names. This time the emails are either in English or Chinese without any translations. Fortunately, the previous story makes it possible for readers who know only either English or Chinese, but not both, to stay on track of the storyline without missing much.

Since the poems in the first part of $A$ Single-Winged Bird are mostly unrelated and without any unified storylines, long and detailed exploration of sexuality seems absent. This is not to say that Edna Wu does not use poetry to express sex and love. In fact almost all of the poems deal with love, with a few suggesting the poet's sexual longing and frustration. In "Travel the West Heaven along Rowing a Crescent Moon," for instance, the persona finds herself unable to think or sleep because of sexual cravings. One can very well assume that the "West Heaven" may refer to America and the traveler, a lonely female immigrant. Sleepless, the persona sighs: "Easy to imagine lust/Hard to lust by skin. How I hate the intertwining of this world/l, a born female vagrant, travel the West Heaven alone, rowing a crescent moon" ( $p$. 10). The poet creates a very sad scene of a woman unable to find peace and gratification because of her failure in materializing her maddening "lust by skin." This is indeed rather pathetic given the length of her repeated quest and repeated failure.

Unlike the loosely clustered poems, the diary in the short story, in contrast to the poems, offers a clear storyline, although the blur between imagination and reality can be a cause for confusion or a source of pleasure depending on the mood of the reader. In one of the middle entries, the diarist tells her reader that she is merely supposing that "DC is an appointed lover, sculptured by my imagination" (p. 120):

\footnotetext{
On the sixth day of each month, I would go to meet him in Olive Garden, sitting always at the same table in a dim corner. Every time I would order two dinners, but eat alone all by myself amid simpering chuckles, and completely forgetting who I am. I would never ask for a doggie bag, but always give a generous tip before leaving. My oddity must have given the servers an eerie feeling of my mysteriousness. Obviously, magnanimity and mysteriousness have made me the most welcomed diner. On the sixth day of each month, they would take care to leave the compartment table in the corner especially for me. If I failed to appear, there must be more than one person feeling disappointed.

Conversing while dining. My words are voiceless and back flowing. Only he, he alone, can hear through the wires of his sixth sense (p. 120).
}

What do they talk about according to the narrator's or the diarist's, imagination? What else except love, romance, and love-making? Although gone are the graphic expressions of sex and straightforward references to the human genitals as were often the case in Clouds and Rain, scenes of sexual acts still dominate the diary entries. Take the April $6^{\text {th }}, 2002$, entry for example. The reader is presented with an intoxicating scene of how the two lovers drop "into that unknown realm of senses" when the "two drenched chicks staggered across the huge kitchen into the indoor spa," "I rub[bing] his back and he massag[ing] my neck and shoulders" (p. 122). The December $6^{\text {th }}$ entry of the same year depicts a similar scene of intense love-making, except that it is more subtle and more artistically done with the author's 
use of the metaphor Xtreme Trek joyride in Magic Mountain, but the familiarity of sexual pleasure and orgasm is inescapable:

I shut my eyes obediently like a timid child. Let the flying churning revolving chair throw me up into the sky and then dump me back to the ground. I was being tortured in unimaginable ways back and forth, left and right, front and behind, top and bottom, spinning like a helpless spindle. I was a tiny boat in a stormy night, completely losing its direction. I was screaming at the top of my voice and howling desperately as if the world met its judgment day.

Screaming, hysterical screaming. Only such scream can relax every nerve of intensive love. Die, let me die like this. Let me die like a fool in the surging waves of the love sea. Only being such a fool can you fully enjoy the thrills of the most dangerous game (p. 135).

The one-way emails that make up the third part of $A$ Single-Winged Bird seem to retell the story of "A Riddle", the 51 years of romance between Edna and DC. This time, instead of focusing on the diarist or the narrator, the emails have an assumed one-member audience: first DC, as in the previous story, later on C. In spite of the email writer's repeated claim that it is their intellectual unison that makes her want to email him and be with him, physical gratification still plays a big part in their relationship. Even though her emails go unanswered, she continues to fantasize about the love they share. She tries desperately to make it clear to him that she needs him body and soul. In one email, written in Chinese without any translation, she tells him one of her affairs that lasted for over six years:

\section{Edna 说她和一位男士保持五六年的矢系，全是他的功劳。他住在地球的另一边，一个月大概能见一两 次面。但他一年三百六十五天，天天打电话，随时互通情报。他简直成了他们之间感情的温度计， Edna 稍有冷漠他便有察觉, 不是自我调整, 便是提出让对方调整。虽然交流重要, 游戏更重要。那位 是不会玩游戏, 只会床上运动, 于是他们俩的矢系濒于有首无身, Edna 时常陷入孤独 (164-165).}

In a nutshell, this Chinese email reveals Edna's love affair with a man who can only talk to her on the phone and make love to her once or twice a month. Not being together with him all the time leaves her feel that the love affair is only focused on the body, not on the mind. That is why she wants to be with $\mathrm{C}$, the intended email recipient. From a different perspective, the above quote also highlights Edna Wu's theme that nothing works in the old world of China. Sex is no exception. In spite of the man's daily phone calls and his powerful moves in bed, the sexual and love relationship simply cannot sustain itself. To fulfill her bodily desires and emotional longings, her female narrator must immigrate to the new land where everything promises to be free, abundant, and gratifying.

Ironically, she is faring no better in the new land because, her emails being only one way, her love is not being reciprocated. In the end, she remains bitterly disappointed. In spite of her decades of perseverance in chasing love, in seeking sexual freedom and fulfillment, and in indulging herself in the process of her quest as she tries to settle in in this new land, she still finds herself "a single-winged bird." Her disappointment, however, does not mean that she regrets her passage to America. Perhaps Edna Wu simply wants her female narrator Edna to tell the reader that uprooting oneself from her homeland to set up a new home in this adopted country will take much longer than expected. So let the pursuit continue. The process, however baffling, is what must be observed, documented, and perhaps even enjoyed and celebrated in its own right.

\section{References}

Bakhtin, M. M. (1981). The dialogic imagination: four essays. (M. Holquist, Ed.). (C. Emerson \& M. Holquist, Trans.). Austin, TX: University of Texas Press.

Gilbert, S. M., \& Gubar, S. (1998). Infection in the sentence: The woman writer and the anxiety of authorship. In D. H. Richter (Ed.), The critical tradition: classic texts and contemporary trends (2nd ed.). (pp. 1360-1373). Boston: Bedford/St. Martin's.

Richter, D. H. (Ed.). (1998). The critical tradition: classic texts and contemporary trends (2nd ed.). Boston: Bedford/St. Martin's.

Wu. E. (1994). Clouds and rain: A China-to-America memoir. Evanston, IL. Evanston Publishing.

Wu, E. (2006). Two Eves in the Garden of Eden and a male mother. Denver, Colorado: Outskirts Press.

Wu, E. (2010). A single-winged bird: poems, a short novel, and one-way emails. USA: Xlibris Corporation.

Wu, Q. (1995). Female rule in Chinese and English literary utopias. Syracuse, NY: Syracuse University Press. 